\title{
ELABORATION OF TECHNOLOGY FOR IMPLEMENTING ORGANIZATIONAL SOLUTIONS ON INNOVATIVE CLUSTERS DEVELOPMENT
}

\author{
Olexandra Farat ${ }^{1}$, Marta Lyvdar ${ }^{2}$
}

\begin{abstract}
The process of cluster paradigm development in Ukraine is characterized by the absence of a clear legal and regulatory framework that would enable the clusters to be identified in the overall set of business entities. It complicates the coordination of the interaction of participants in the cluster process, as well as processes related to the creation and development of other innovation-oriented business structures. Significant impact is the availability of the weak information support, the task of which is to establish business communications between the state and business, on issues of ensuring the maximum possible realization of the existing innovative potential, in particular, by commercializing progressive innovations. Therefore, the particular topicality gets the issue of building a structured institutional environment that determines the clear mechanisms for the development of the most innovative business structures in Ukraine. The purpose of the researches was to develop specific mechanisms for organizing synergistic interaction of all participants in the process of creation and development of clusters in Ukraine in the context of multilevel sectors of their functioning. To achieve the goal, the following tasks were solved: the world tendencies of modern innovative development were investigated; the change of Ukraine's positions during 2014-2017 in innovation rankings was considered; the state of development of innovative entrepreneurship in Ukraine was analysed; a system of scenarios for the organization of technological solutions for the development of innovative clusters was proposed; the indicator of the evaluation of the cluster paradigm development in the regions for the purpose of determining the useful effect from its implementation was presented. Considered changes in Ukraine's positions in 2010-2017 in innovation rankings and indicators of the provision of innovation development in Ukraine in 2010-2017 state the extremely low level of state interest in creating, internal commercializing, and promoting to the external market own innovative technologies, and in the development of the very innovative business, which, in turn, reflects on the ability of enterprises to develop their innovative potential. The proposed system of scenarios for the organization of technological solutions for the development of innovative clusters includes four possible technologies for the creation of clusters, which are united in two blocks: technologies in the sector of state entrepreneurship - the source of stimulation are state institutions and technologies in the sector of private entrepreneurship - the source of initial incentives are business entities themselves. Using the proposed indicator of the expediency of cluster paradigm development in the regions to determine the useful effect from its implementation (IRCD), it is possible to estimate the influence of clusters on the development of the economy in the region.
\end{abstract}

Key words: innovation development, cluster association, cluster background, cluster creation technology, cluster development.

JEL Classification: O30, O33, R11, O57

\section{Introduction}

The current process of cluster paradigm development in Ukraine is characterized by the absence of a clear legal and regulatory framework that would enable the clusters to be identified in the overall set of business entities and identified possible mechanisms for their creation and development.

Corresponding author:

${ }^{1}$ Lviv Polytechnic National University, Ukraine.

E-mail: farat_o@ukr.net

${ }^{2}$ Lviv Polytechnic National University, Ukraine.

E-mail:m.luvdar@gmail.com
This greatly complicates the coordination of the interaction of participants in the cluster process, as well as processes related to the creation and development of other innovationoriented business structures (industrial parks, business incubators, etc.) in order to ensure the stable maintenance of their high competitive positions in the global space. 
The process of effective clusterization of the national economy taking into account modern economic realities requires a deep systemic approach of the directed and complete transformation of the existing institutional environment through its functional structuring. Such functional structuring should provide a clear separation of all processes necessary for the effective development of the cluster paradigm: legal support - necessary for the clear identification of clusters among other business entities, software - necessary to stimulate and interest the economic entities themselves in creating clusters, information provision - necessary for the organization of effective interaction of all participants in the process of creating clusters and providing tools of analytical evaluating of their practical usefulness for regional economies and the economy as a whole.

The topicality of the development of a cluster paradigm issue leads to an increase in the number of researchers who pay their attention to clusters. Among domestic scientists dealing with research on the possibilities of cluster development and their impact on the growth of the competitiveness of the economy are: Z. S. Varnaliy, I. O. Degtyariova, O. Y.Zhabynets, G. T. Pyatnytska, and others. Among foreign scientists, the issue of clusters was particularly active in the research of Michael Porter, G. Lindquist, S. Rosenfeld, E. Glazer and others.

The key attention in the works of these scholars was given to the study of the essence of the notion of "cluster" as a subject of market relations and its impact on the growth potential of the competitiveness of the economy. The research is devoted to the comprehensive study of organizational decisions regarding the development of innovative clusters, which are rather superficial, especially from the side of domestic scientists.

The research is aimed at developing mechanisms for organizing synergistic interaction of all participants in the process of creation and development of clusters in Ukraine, for which the following tasks were solved: the world trends of modern innovation development were investigated, a system of scenarios for organizing technological solutions for the development of innovative clusters was presented, an indicator for evaluating the feasibility of cluster paradigm to determine the useful effect of its implementation was suggested.

\section{Research of world tendencies of modern innovative development}

The current development of an innovative economy in the world can be estimated by analysing the expenditure on innovation in the world. There are listed the world leaders for the cost of innovative development in 2016 in Table 1 (website of the Forbes Magazine, 2016).

Countries, depending on their influence on the formation of the world's innovation economic policy, are divided into three groups, namely, Asian, North American, and European.
Table 1

World leaders of innovative development financing in 2016

\begin{tabular}{|l|c|c|}
\hline \multicolumn{1}{|c|}{ Country } & $\begin{array}{c}\text { Expenditures on } \\
\text { innovation, billion USD }\end{array}$ & $\begin{array}{c}\text { Cost share } \\
\text { in GDP, \% }\end{array}$ \\
\hline United States & 405 & 2,7 \\
\hline China & 338 & 2,1 \\
\hline Japan, & 160 & 3,7 \\
\hline Germany & 70 & 2,3 \\
\hline South Korea & 65 & 4,4 \\
\hline France & 42 & 1,9 \\
\hline United Kingdom & 38 & 1,7 \\
\hline India & 35 & 0,9 \\
\hline Russia & 33 & 1 \\
\hline Canada & 24 & 1,8 \\
\hline Ukraine & 0,62 & 0,8 \\
\hline
\end{tabular}

The Asian group is represented by countries such as China, Japan, South Korea, and India with a total expenditure innovation of $\$ 598$ billion; The North American group includes the United States and Canada with a combined innovation cost of $\$ 429$ billion. The European group includes Germany, France, the United Kingdom, and Russia with a total expenditure on innovation in the amount of 183 billion USD.

The most important influence on the development of innovations in the world is made by the North American group of countries. Thus, according to TOP-50 ranking of the most innovative companies in the world in 2016 published by Forbes Magazine from 50 companies of leaders, 33 (66\%) companies are American, 10 (20\%) are European, and only 7 (14\%) are Asian.

In its turn, the top five include: Apple, Google, Tesla Motors, Microsoft, Amazon (website of the Forbes Magazine, 2017). Three companies of five deal with information technology, e-commerce, and one, namely Tesla Motors is an American automobile startup from Silicon Valley. Consequently, the very development of information technology today is one of the key global trends in the development of an innovative economy.

\section{Consideration of changes in Ukraine's positions in 2010-2017 in the global innovation rankings, the ranking of doing business, competitiveness, and indicators of the provision of innovation development in Ukraine in 2011-2016}

As for Ukraine, in order to more accurately assess the current state of the domestic economy, we will analyse Ukraine's place in such world rankings as: Global Innovation Index (website of the World Intellectual Property Organization, 2014-2017), Global Competitiveness Index (website of the World Bank, 2014-2017), and Doing Business Index (website of the World Economic Forum, 2014-2017). 
The data in Table 2 show that Ukraine holds indirect positions according to the Global Innovation Index but there is a tendency for its improvement, that is, there is a slight increase in the estimation of Ukraine's innovative development in the global economic space during the investigated period.

Table 2

Places of Ukraine in global rankings in 2014-2017

\begin{tabular}{|c|c|c|}
\hline Years & $\begin{array}{c}\text { Places of Ukraine in } \\
\text { rankings/Total number } \\
\text { of evaluated states } \\
\text { Global Innovation Index }\end{array}$ & Index values \\
\hline \multicolumn{3}{|c|}{} \\
\hline 2014 & $63 / 143$ & 36,26 \\
\hline 2015 & $64 / 141$ & 36,45 \\
\hline 2016 & $56 / 128$ & 35,72 \\
\hline 2017 & $50 / 127$ & 37,62 \\
\hline \multicolumn{3}{|c|}{ Doing Business Index } \\
\hline 2014 & $159 / 189$ & 61,52 \\
\hline 2015 & $146 / 189$ & 63,04 \\
\hline 2016 & $143 / 190$ & 63,90 \\
\hline 2017 & $140 / 190$ & 65,75 \\
\hline \multicolumn{3}{|c|}{ Global Competitiveness Index } \\
\hline 2014 & $84 / 148$ & 4,05 \\
\hline 2015 & $76 / 144$ & 4,14 \\
\hline 2016 & $79 / 140$ & 4,03 \\
\hline 2017 & $85 / 138$ & 4,0 \\
\hline
\end{tabular}

As for the Doing Business Index, Ukraine is an outsider but at a low pace, Ukraine's assessment by this indicator in the global space also grows during 2014-2017. As for the Global Competitiveness Index, this indicator shows a weakening of Ukraine's position in the global economic environment.

Analysing the abovementioned indexes, it is stated the fact of the extremely low level of state interest in the creation, commercialization, promotion of own innovative technologies on the external market, and the development of the very innovative entrepreneurship. Unfortunately, domestic legislation does not provide conditions for the effectiveness of tax incentives for the development of innovative entrepreneurship. State programs for stimulating entrepreneurship development are not system-oriented; target financing, provided by state programs, is not always sufficient and does not allow meeting the needs of economic entities in full; there is a significant amount of bureaucratic barriers from registration processes to closing enterprises, etc.

Here is an example ofGeorgia, where in order to implement the procedure for registration of ownership of enterprises, it was necessary to carry out only one procedure, and the procedure itself will last one day; in Belarus, it is necessary to pass 2 procedures, and the process takes 3 days; in Moldova, respectively, 5 and 5.5; in Kyrgyzstan and Kazakhstan 3 procedures and 3.5 days. In Ukraine, a business must pass 7 formal procedures and expect a registration within 23 days (website of the Economic Discussion Club, 2017).
The availability of highly skilled scientific personnel and adequate level of financing is important for ensuring stable innovative development in the state. Table 3 provides data on some indexes of innovative development in Ukraine during 2011-2016 (Verner, 2017).

Data in Table 3 shows that during the research period, there was an annual decrease in the number of employees involved in the implementation of research; more than half of the research is devoted to new products, not processes.

Table 3

Indexes of the provision of innovative development in Ukraine during 2011-2016

\begin{tabular}{|c|c|c|c|c|c|}
\hline Year & 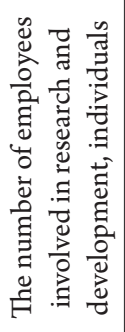 & 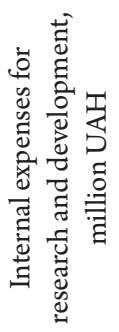 & 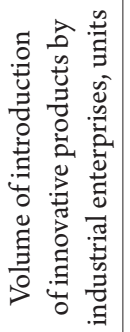 & 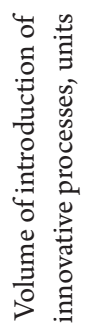 & 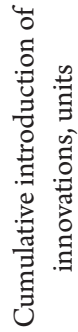 \\
\hline 2011 & 182484 & 8107,1 & 2408 & 2043 & 4451 \\
\hline 2012 & 175330 & 8513,4 & 3238 & 2510 & 5748 \\
\hline 2013 & 164340 & 9419,9 & 3403 & 2188 & 5591 \\
\hline 2014 & 155386 & 10248,5 & 3138 & 1576 & 4714 \\
\hline 2015 & 136123 & 9487,5 & 3661 & 1743 & 5404 \\
\hline 2016 & 122504 & 11003,6 & 3136 & 1217 & 4353 \\
\hline
\end{tabular}

It should also be taken into account that one of the factors that influence the reduction of scientific personnel in Ukraine is "brain drain", which has a significant negative impact on the formation and development of the state's innovative potential.

\section{Analysis of the state of innovative entrepreneurship development in Ukraine}

We will evaluate the First Ranking of Innovative Companies of Ukraine, which was compiled by Forbes Magazine in 2016.

According to this ranking, the most innovative companies in Ukraine are the following (Table 4).

According to the data of Table 4, the largest share of innovative enterprises in Ukraine, on the type of economic activity carried out in the agro-industrial complex accounts for $25 \%$ of the total, $15 \%$ belongs to the technology sector, $10 \%$ for pharmaceuticals, machine building, alternative energy, and $5 \%$ for finance, cargo transportation, fuel and energy complex, militaryindustrial complex, electronic commerce, and retail.

Less than half of these enterprises can be considered as the central (sound) enterprises, in particular, Yuzhmash, Turboatom, Ukroboronprom, Grammarly, Wind Power, Petcube, Drone.ua, Eco-Optima, to create innovative clusters focused on the production of hightech innovative products. 
Table 4

Ranking of Innovative Companies of Ukraine in 2016

\begin{tabular}{|c|c|c|}
\hline Companies & Types of economic activity & The value of the innovation index \\
\hline Privatbank & Finance & 79,2 \\
\hline Yuzhmash & Machine-building & 64,6 \\
\hline Nova Poshta & Cargo transportation Pharmaceuticals & 60,4 \\
\hline Farmak & Pharmaceuticals & 60,4 \\
\hline Turboatom & Machine-building & 58,3 \\
\hline Grammarly & Technologies & 56,3 \\
\hline Naftogazvydobuvannya & Fuel and energy complex & 54,2 \\
\hline MHP & Agroindustrial complex & 54,2 \\
\hline Ukrboronprom & Military-industrial complex & 52,1 \\
\hline Rozetka & E-commerce & 52,1 \\
\hline Silpo & Retail & 52,1 \\
\hline Wind Power & Renewable energy & 50,0 \\
\hline Darnitsa & Pharmaceuticals & 47,9 \\
\hline Petcube & Technologies & 45,8 \\
\hline Nibulon & Agroindustrial complex & 43,8 \\
\hline Drone.ua & Technologies & 41,7 \\
\hline Eco-Optima & Alternative energy & 41,7 \\
\hline Svarog West Group & Agroindustrial complex & 41,7 \\
\hline AgriLab & Agroindustrial complex & 40,4 \\
\hline Kernel & Agroindustrial complex & 33,3 \\
\hline
\end{tabular}

\section{The proposed system of scenarios for the organization of technological solutions for the development of innovative clusters}

Studies have shown that the development of information technology and automotive are the most dynamic industries. Ukraine has significant potential in these sectors; in particular, in Western Ukraine, there is a cluster of information technologies that should be considered as a background ${ }^{1}$ for the creation of the future Silicon Valley in Ukraine.

Also, the concern "Electron" which strategically can be regarded as one of the enterprises that will act as the core of a powerful machine-building cluster has actively started working today.

One of the keys to the successful development of clusters, taking into account the world practice of the EU, North America, and developed countries in Asia, is the formation of a structured institutional framework for the functioning of clusters, characterized by the presence of the following functional blocks, namely: the legal framework for the identification of clusters as economic entities, software tools for supporting and stimulating the development of clusters; mechanisms of information interaction of all participants of cluster work (processes of creation and development of clusters).

In Ukraine, there is no institutional environment for cluster associations of enterprises today, as clusters are not even identified in domestic economic legislation as an independent economic entity, which is reflected in the absence of official statistical information on the state and dynamics of their development in the regions. Therefore, we proposed an example of a mechanism for providing information support for the development of innovative clusters in Ukraine aimed at systematically improving the institutional foundations for the development of innovation entrepreneurship in Ukraine by establishing clear algorithms for the creation and identification of clusters of enterprises.

Within the framework of the proposed structure of the institutional environment for the development of clusters and taking into account previous researches, four possible technologies of cluster creation (cluster scenario $)^{2}$ can be distinguished, which are united into two blocks: technologies in the sector of state enterprise - the source of stimulation are state institutions and technologies in the sector of private entrepreneurship - the source of initial incentives are the business entities themselves.

The following scenarios for the creation of clusters are possible in the public sector: the top-level scenario and the regional scenario.

The main stages of the proposed "top-level" scenario: 1) the relevant ministry submits recommendations to the Ministry of Economic Development and Trade of Ukraine regarding the possible development of a particular cluster (clusters) in its sector (sectors);

\footnotetext{
${ }^{1}$ Background of cluster - pre-formed conditions in the economic and legal environment of the state for the development of cluster associations of enterprises through the modification of the strategic vision of their development by business entities by combining existing independent enterprises; addition of existing associations by new participants (research institutes, territorial authorities, other enterprises, etc.).

${ }^{2}$ Cluster Creation Technology (Cluster Scenario) is a set of regulatory, investment, financial, information, and other organizational decisions resulted by the civic actions of all interested parties aimed at creating new and developing existing cluster associations of enterprises.
} 
2) the Ministry of Economic Development and Trade of Ukraine (MEDTU) together with the Ministry of Finance of Ukraine (MFU) assess the economic feasibility of setting up a cluster (clusters) in a particular industry (industries);

3) the results of the evaluation of the MEDTU and the MFU are submitted for consideration and approval by the Cabinet of Ministers of Ukraine (CMU);

4 ) in case of a positive decision, the CMU coordinates work with the relevant territorial authority;

5) the territorial authority establishes communication between potential members of a cluster association and defines the process of organizing the creation of a cluster (a plan of successive actions to set up a cluster with their subsequent regulation through the removal of predetermined or addition of new members, distributes and redistributes allocated by the state financial resources for the creation of a cluster, etc.);

6) regional investment and development centres monitor the implementation of cluster-building activities in the regions, as well as evaluate the efficiency of their work, in particular by consolidating data on the economic efficiency of their work (calculation and analysis of the regional cluster development index and other indicators).

Regarding the stages of the regional scenario (the source of the initial incentive will be the territorial authority), they imply:

1) the territorial authority submits recommendations to the relevant ministry regarding the issue of the possible development of the cluster;

2) the relevant ministry examines this proposal and, upon approval, submits to the MEDTU;

3 ) the following steps are similar to the steps in the previous scenario.

In the private entrepreneurship sector, the following scenarios for cluster creation are possible: the scenario of "independent business entities", the "top-level" scenario, and the "implicit cluster" scenario.

The scenario of "independent economic entities" (the source of initial incentives is independent economic entities) involves the following stages:

1) on their own accord, economic entities submit an application for the consideration of the territorial authority for the desire to unite in the cluster association of enterprises;

2) upon approval, the territorial authority transfers this proposal to the relevant ministry, and then the stages are similar to the previous scenario.

The scenario of an "implicit cluster" (enterprises do not create a regulated cluster but formally unite in a non-cluster business association or are unrecognized associations but operate on a cooperative basis as independent economic entities by concluding cooperation agreements) implies:

1) monitoring the work of non-cluster associations with regional investment and development centres, which, analysing data on the activities of unofficially recognized clusters of associations of economic entities, will make recommendations to local authorities regarding their possible transformation into an officially recognized cluster association;

2) the stages are analogous to the scenario of "independent economic entities".

\section{The indicator of the evaluation of the expediency of the cluster paradigm development in the regions}

In determining the expediency of the cluster paradigm development in the regions, it is also important to assess the beneficial effect for regions from its implementation. For this purpose, we propose the following indicator, namely, the regional cluster development index (IRCD).

$$
I R C D=\operatorname{sign}\left(1-\frac{C D}{N P C}\right) \times\left(\frac{R I C}{R I O E}+\frac{C P R B}{C P O E}+\frac{V E I P C}{V E I P O E}\right),
$$

where $C D$ - is the amount of losses incurred by innovative clusters in the region during the reporting period, thousand UAH;

NPC - the amount of total net profit received by innovative clusters in the region during the reporting period, thousand UAH;

RIC - the amount of real cluster investments in the development of the regional economy during the reporting period, thousand $\mathrm{UAH}$;

RIOE - the amount of real investments in the development of the regional economy, invested in other economic entities during the reporting period, thousand UAH;

CPRB - the amount of the cluster revenues to the regional budget during the reporting period, thousand UAH;

CPOE - the amount of revenues from other economic entities to the regional budget during the reporting period, thousand $\mathrm{UAH}$;

VEIPC - the amount of sold innovative products for export by clusters in the region during the reporting period, thousand UAH;

VEIPOE - the amount of sold innovative products for export, thousand UAH.

The analysis of this indicator is recommended as a holistic in dynamics and in accordance with its structural elements.

When calculating the component of the stage of development of clusters $\left(1-\frac{C D}{N P C}\right)$ using the sign function, the following values can be obtained:

1) “ +1 " - cluster profits in the region exceeded the losses in the period under study;

2) "-1" - the losses incurred by clusters in the region exceed their net profits in the investigated period. This situation is normal for newly formed clusters but in the dynamics, this indicator should become positive;

3 ) " 0 " - net profits received by clusters are equal to the losses received in the investigated period (the practical 
absence of a beneficial effect of clusters for the regional economy in the investigated period, which is unlikely).

It is also advisable to analyse the function arguments. After the analysis, the $\mathrm{CD}$ value should go to 0 , and the NPC - to grow.

Analysing relevant relationships, one can assess the impact of clusters on the development of a real economy in the region $\left(\frac{R I C}{R I O E}\right)$, the impact of clusters on filling regional budgets $\left(\frac{C P R B}{C P O E}\right)$, the impact of clusters on the formation of the foreign trade balance of regions $\left(\frac{V E I P C}{V E I P O E}\right)$. This indicator should be calculated both in the region as a whole and in the context of the proposed scenarios, which will determine the most effective ones for specific regions, taking into account their economic, social, natural, and other conditions.

\section{Conclusion}

Thus, tasks set for the authors are solved in full. The study of world trends in modern innovation shows that in today's global economic environment, there are three key groups of countries that influence the formation of a global innovation economic policy, namely: Asian, North American, and European. The most important influence on the development of innovations in the world is exactly the North American group of countries, and the development of information technology today is one of the key global trends in the development of the innovative economy.

The considered changes in Ukraine's positions during 2011-2017 in global innovation rankings state the fact of the extremely low level of state interest in the creation, internal commercialization, and promotion of its own innovative technologies on the external market, and in the development of innovative entrepreneurship, which in turn reflects on the ability of enterprises to develop its innovative potential.

The analysis of the state of innovative entrepreneurship development in Ukraine shows that the largest share of innovative enterprises of Ukraine, according to the type of economic activity carried out, the agro-industrial complex accounts for $25 \%$ of the total, $15 \%$ belongs to the technology sector, $10 \%$ for pharmaceuticals, machine building, alternative energy, and 5\% for finance, cargo transportation, fuel and energy complex, militaryindustrial complex, electronic commerce, and retail.

Less than half of these enterprises can be considered as the central (sound) enterprises, in particular, Yuzhmash, Turboatom, Ukroboronprom, Grammarly, Wind Power, Petcube, Drone.ua, Eco-Optima, to create innovative clusters focused on the production of hightech innovative products.

The proposed system of scenarios for the organization of technological solutions for the development of innovative clusters includes four possible technologies for the creation of clusters (cluster scenario), which are united in two blocks: technologies in the sector of state entrepreneurship, and technologies in the sector of private entrepreneurship.

For the study of the effectiveness of the implementation of the cluster strategy in the regions, a comprehensive indicator of the feasibility of the cluster paradigm development in the regions was proposed for determining the useful effect from its implementation (IRCD), and it can be used to estimate the influence of clusters on the development of the economy in the region, the influence of clusters on the filling of regional budgets, and the influence of clusters on the formation of foreign trade balance of the regions.

\section{References:}

Fundeanu, D., Badele, C. (2014). The Impact of Regional Innovative Clusters on Competitiveness. Procedia. Social and Behavioral Sciences Journal, 124, 405-414.

«Forbes»[Forbes magazine]. Retrieved from: http://forbes.net.ua/ua/magazine/forbes/1416757-vryatuvatimajbutne-pershij-rejting-innovacijnih-kompanij-ukrayini

«Forbes» [Forbes magazine]. Retrieved from: http://forbes.net.ua/ua/news/1426818-top-50-najbilshinnovacijnih-kompanij-svitu

Svitova orhanizatsiia intelektualnoi vlasnosti [World Intellectual Property Organization]. Retrieved from: http://www.wipo.int/publications/en/details.jsp?id=4193

Svitovyi bank [World Bank]. Retrieved from: http://www.doingbusiness.org/reports/global-reports/doingbusiness-2018

Vsesvitnii ekonomichnyi forum [World Economic Forum]. Retrieved from: https://www.weforum.org/reports

Ekonomichnyi dyskusiinyi klub [Economic Discussion Club]. Retrieved from: http://edclub.com.ua/analityka/ doing-business-2017-ukrayina-v-reytyngu-svitovogo-banku-legkosti-vedennya-biznesu

Verner, I. Y. (2017). Ukraina u syfrakh 2016 [Ukraine in numbers 2016]. Kyiv: Derzhavna sluzhba statystyky Ukrainy. (in Ukrainian)

Wolman, H., Hincapie, D. (2015). Clusters and Cluster-Based Development Policy. Economic Development Quarterly: SAGE Journal, 2, 135-149. 